\title{
Improved milk production efficiency in early lactation dairy cattle with dietary addition of a developmental fibrolytic enzyme additive
}

\author{
L. Holtshausen, ${ }^{*}$ Y.-H. Chung, ${ }^{*}$ H. Gerardo-Cuervo, † M. Oba, $†$ and K. A. Beauchemin ${ }^{\star 1}$ \\ *Agriculture and Agri-Food Canada, Lethbridge, AB, T1J 4B1 Canada \\ †Department of Agriculture, Food and Nutritional Science, University of Alberta, Edmonton, AB, T6G 2P5 Canada
}

\begin{abstract}
A 3-part study was conducted to evaluate the effect of a developmental fibrolytic enzyme additive on the digestibility of selected forages and the production performance of early-lactation dairy cows. In part 1, 4 replicate 24 -h batch culture in vitro incubations were conducted with alfalfa hay, alfalfa silage, and barley silage as substrates and ruminal fluid as the inoculum. A developmental fibrolytic enzyme additive (AB Vista, Marlborough, UK) was added at 5 doses: $0,0.5,1.0$, 1.5 , and $2.0 \mu \mathrm{L} / \mathrm{g}$ of forage dry matter (DM). After the 24-h incubation, DM, neutral detergent fiber (NDF), and acid detergent fiber (ADF) disappearance were determined. For alfalfa hay, DM, NDF, and ADF disappearance was greater at the highest dosage compared with no enzyme addition. Barley silage NDF and ADF and alfalfa silage NDF disappearance tended to be greater for the highest enzyme dosage compared with no enzyme addition. In part 2, 6 ruminally cannulated, lactating Holstein dairy cows were used to determine in situ degradation of alfalfa and barley silage, with $(1.0 \mathrm{~mL} / \mathrm{kg}$ of silage DM) and without added enzyme. Three cows received a control diet (no enzyme added) and the other 3 received an enzyme-supplemented (1.0 $\mathrm{mL} / \mathrm{kg}$ of diet DM) diet. Enzyme addition after the 24 $\mathrm{h}$ in situ incubation did not affect the disappearance of barley silage or alfalfa silage. In part 3, 60 earlylactation Holstein dairy cows were fed 1 of 3 diets for a 10-wk period: (1) control (CTL; no enzyme), (2) low enzyme (CTL treated with $0.5 \mathrm{~mL}$ of enzyme $/ \mathrm{kg}$ of diet $\mathrm{DM}$ ), and (3) high enzyme (CTL treated with $1.0 \mathrm{~mL}$ of enzyme $/ \mathrm{kg}$ of diet DM). Adding enzyme to the diet had no effect on milk yield, but dry matter intake was lower for the high enzyme treatment and tended to be lower for the low enzyme treatment compared with CTL. Consequently, milk production efficiency ( $\mathrm{kg}$ of $3.5 \%$ fat-corrected milk/kg of DM intake) linearly increased with increasing enzyme addition. Cows fed the low and
\end{abstract}

Received January 28, 2010.

Accepted November 1, 2010.

${ }^{1}$ Corresponding author: karen.beauchemin@agr.gc.ca high enzyme diets were 5.3 (not statistically significant) and $11.3 \%$ more efficient, respectively, compared with CTL cows. This developmental fibrolytic enzyme additive has the potential to increase fiber digestibility of forages, which could lead to greater milk production efficiency for dairy cows in early lactation.

Key words: fibrolytic enzyme, dairy cow, milk production efficiency

\section{INTRODUCTION}

Beauchemin et al. (2003b) reported overall increases of $1.0 \pm 1.3 \mathrm{~kg} / \mathrm{d}$ in DMI and $1.1 \pm 1.5 \mathrm{~kg} / \mathrm{d}$ in milk yield with the addition of fibrolytic exogenous enzymes to dairy cow diets when combining data from 20 studies and 41 treatments. It is clear from the standard deviations that responses to adding fibrolytic enzymes to ruminant diets have been variable. It is therefore not surprising that the use of fibrolytic enzyme products in commercial dairy operations has not yet been widely adopted. However, continuing increases in feed costs and consumer concerns about the use of growth promoters and antibiotics in livestock production provide ample incentive to revisit and refine the use of enzyme feed additives in ruminant diets as a means of improving feed conversion efficiency and lowering the cost of milk production.

Exogenous feed enzymes that contain fibrolytic activities may help enhance fiber digestion in the rumen (Feng et al., 1996; Yang et al., 1999; Kung et al., 2000), which could lead to improved feed conversion efficiency. Improvements in ruminal fiber digestibility of feed would also allow dairy producers to feed higher forage diets or high-fiber byproduct feeds without compromising energy intake or animal productivity.

Fibrolytic enzyme additives of interest for ruminants are concentrated fermentation products containing a broad spectrum of carbohydrases, including cellulases and hemicellulases. However, most commercial enzyme products containing cellulases and xylanases have been designed for use in the food, textile, or chemical industries (Bhat and Hazlewood, 2001). Enzyme activities provided by the manufacturers for these products have 
been determined under conditions most favorable for the specific enzymatic activity ( $\mathrm{pH} 4.5$ to $5.5,45$ to $60^{\circ} \mathrm{C}$ ) and can vary substantially under different conditions (Kung et al., 2002). Colombatto and Beauchemin (2003) therefore recommended that the enzymic activities of enzyme products intended for ruminant use be determined at $\mathrm{pH} 6.0$ to 6.5 and $39^{\circ} \mathrm{C}$. Beauchemin et al. (2003a) also proposed using in vitro techniques to screen potential products for improvements in NDF degradability before embarking on the necessary, but more costly, in vivo validation.

This logical stepwise approach has not been used to evaluate potential exogenous fibrolytic enzyme products for use in ruminant diets. We obtained a developmental exogenous fibrolytic enzyme product and set out to determine its potential for use in ruminant diets following the steps proposed by Colombatto and Beauchemin (2003) and Beauchemin et al. (2003a). We hypothesized that the developmental enzyme product would increase fiber digestibility of alfalfa hay, alfalfa silage, and barley silage in vitro or in situ, and that feed efficiency or milk production of dairy cows in early lactation would be improved when the cows were fed a diet containing these 3 forages supplemented with the enzyme additive.

\section{MATERIALS AND METHODS}

A 3-part study, including an in vitro fermentation, an in situ incubation, and a lactation study, was conducted to evaluate the effect of a developmental fibrolytic enzyme additive on the digestibility of selected forages and the production performance of early-lactation dairy cows. All cows were cared for in accordance with the guidelines of the Canadian Council on Animal Care (1993).

\section{In Vitro Fermentation}

This study was conducted at the Agriculture and Agri-Food Canada's Research Centre in Lethbridge, Alberta, Canada. Four replicate, 24-h batch culture in vitro incubations (i.e., 1 run each on 4 separate days with different inocula) were conducted in a completely randomized design with alfalfa hay, alfalfa silage, and barley silage as substrates and ruminal fluid as the inoculum. A representative sample of each substrate was dried at $60^{\circ} \mathrm{C}$ for $48 \mathrm{~h}$ and ground through a 1-mm-screen Wiley mill (standard model 4, Arthur H. Thomas, Philadelphia, PA). Approximately $0.9 \pm 0.01$ g DM of substrate was weighed into 5 replicate filter bags (F57, Ankom Technology, Macedon, NY) for each forage $\times$ enzyme $\times$ dose combination.
The developmental (i.e., not commercially available) enzyme product (Econase RDE, AB Vista, Marlborough, UK) was added as a liquid $(100 \mu \mathrm{L})$ directly onto the substrate in the filter bags at 4 doses: $0.5,1.0,1.5$, and $2.0 \mu \mathrm{L} / \mathrm{g}$ of substrate DM. Endoglucanase (EC 3.2.1.4) and xylanase (EC 3.2.1.8) activities for the batch of Econase RDE used in the study were 722 and 2,604 $\mathrm{nmol} / \mu \mathrm{L}$ of enzyme product, respectively. Enzymatic activity was determined at $39^{\circ} \mathrm{C}$ and $\mathrm{pH} 6.0$ using lowviscosity carboxymethyl cellulose (Sigma Chemical Co., St Louis, MO; catalog no. C-5678) and birchwood xylan (Sigma Chemical Co., catalog no. X-0502) as substrates (10 $\mathrm{mg} / \mathrm{mL}$ in $0.1 M$ citrate phosphate buffer, $\mathrm{pH} 6.0$ ), following the procedures outlined by Wood and Bhat (1998) and Bailey et al. (1992) for endoglucanase and xylanase activities, respectively. An equal amount of distilled water was added to a set of filter bags to serve as the control (CTL; no enzyme added).

The filter bags were then heat-sealed and placed individually into $250-\mathrm{mL}$ glass vials. Two hours later, $60 \mathrm{~mL}$ of buffered medium (Goering and Van Soest, 1970) was added to each glass vial and the vial closed with a rubber stopper. The vials were kept at room temperature for $20 \mathrm{~h}$ and then transferred to an incubator at $39^{\circ} \mathrm{C}$ to prewarm before adding $15 \mathrm{~mL}$ of inoculum to each vial approximately 60 min later. For the inoculum, ruminal contents were obtained approximately $3 \mathrm{~h}$ after the morning feeding from 2 cannulated cows receiving a barley silage-based TMR with a 50:50 forage to concentrate ratio (DM basis). The ruminal fluid was strained through a polyester screen (PECAP, pore size $355 \mu \mathrm{m}$; B \& S H Thompson, Ville MontRoyal, Quebec, Canada) into an insulated thermos, pooled across the 2 cows, and immediately transported to the laboratory. After adding the inoculum to the prewarmed, buffered medium, the vials were again sealed with rubber stoppers, crimp-sealed to avoid gas leakage, and placed on a rotary shaker platform at 120 $\mathrm{rpm}$ in the $39^{\circ} \mathrm{C}$ incubator. After the 24 -h incubation, fermentation was terminated by exposing the samples to oxygen. The filter bags were removed from the vials, rinsed under a gentle stream of cold water until the water ran clear, and placed in a $60^{\circ} \mathrm{C}$ oven for $48 \mathrm{~h}$ to determine DM disappearance. Sequential NDF and ADF analyses were performed to determine NDF and ADF disappearance (Ankom ${ }^{200}$ Fiber Analyzer, Ankom Technology, Macedon, NY).

\section{In Situ Incubation}

The study was conducted at the University of Alberta Dairy Research and Technology Center (DRTC), Edmonton, Alberta, Canada. Six ruminally cannulated, 
Table 1. Ingredients and chemical composition (mean \pm SD) of the control diet (no enzyme added) used for the in situ and lactation study

\begin{tabular}{lc}
\hline & \% of \\
Item & diet DM \\
\hline Ingredient $^{1}$ & \\
Barley silage $^{2}$ & 20.6 \\
Alfalfa silage $^{3}$ & 20.6 \\
Alfalfa hay $^{4}$ & 10.8 \\
Barley grain, steam rolled & 9.52 \\
Corn grain, steam rolled & 8.88 \\
Bypass soybean meal & \\
Corn, dry ground & 6.60 \\
Barley, dry ground & 6.00 \\
Soybean meal & 5.16 \\
Corn distillers grain with solubles & 4.32 \\
Canola meal & 3.36 \\
Limestone & 2.52 \\
Sodium bicarbonate & 0.41 \\
Salt & 0.39 \\
Magnesium oxide & 0.33 \\
Dicalcium phosphate & 0.19 \\
Trace mineral premix & 0.17 \\
Chemical composition & 0.15 \\
DM & \\
OM, \% of DM & $52.9 \pm 3.62$ \\
CP, \% of DM & $89.5 \pm 0.56$ \\
NDF, \% of DM & $20.0 \pm 1.00$ \\
ADF, \% of DM & $33.9 \pm 1.82$ \\
\hline
\end{tabular}

${ }^{1}$ All ingredients except alfalfa hay, alfalfa silage, and barley silage were provided as part of a ground concentrate mix.

${ }^{2}$ Composition (DM basis): $35.3 \% \mathrm{DM}, 15.0 \% \mathrm{CP}, 53.2 \% \mathrm{NDF}$, and $34.2 \% \mathrm{ADF}$.

${ }^{3}$ Composition (DM basis): $39.8 \%$ DM, $18.9 \% \mathrm{CP}, 37.2 \% \mathrm{NDF}$, and $32.2 \%$ ADF.

${ }^{4}$ Composition (DM basis): $89.5 \%$ DM, $16.8 \% \mathrm{CP}, 47.4 \% \mathrm{NDF}$, and $36.6 \%$ ADF.

${ }^{5}$ Aminoplus (Ag Processing Inc., Omaha, NE).

${ }^{6}$ Added to supply per kilogram of dietary DM: $65 \mathrm{mg}$ of Mn, $110 \mathrm{mg}$ of $\mathrm{Zn}, 37 \mathrm{mg}$ of $\mathrm{Cu}, 1 \mathrm{mg}$ of $\mathrm{Co}, 0.30 \mathrm{mg}$ of Se, 8,336 IU of vitamin A, $834 \mathrm{IU}$ of vitamin D, and $56 \mathrm{IU}$ of vitamin E.

lactating Holstein dairy cows $(120 \pm 52$ DIM $)$ were used. Three cows received a CTL diet (no enzyme) and the other 3 received an enzyme-supplemented diet (CTL diet treated with $1.0 \mathrm{~mL}$ of Econase RDE $/ \mathrm{kg}$ of TMR DM). For the treatment diet the appropriate amount of Econase RDE was diluted with water to supply $4 \mathrm{~L}$ of the dilution per $100 \mathrm{~kg}$ of TMR DM. The dilution was added to the TMR at the time of mixing, usually within an hour before feeding. An equal amount of water $(4 \mathrm{~L} / 100 \mathrm{~kg}$ of TMR DM) was added to the CTL diet. The composition of the CTL diet and the nutrient content are presented in Table 1.

An in situ technique was used to estimate DM, NDF, and ADF disappearance of alfalfa and barley silage (Huntington and Givens, 1995). Fresh silage samples were processed with a Knifetec 1095 sample mill (Foss Tecator, Höganäs, Sweden) for $5 \mathrm{~s}$ and then divided in 2 equal portions. One portion of each type of silage was treated with Econase RDE at a rate of $1.0 \mathrm{~mL} / \mathrm{kg}$ of silage DM. Approximately $5 \mathrm{~g}$ DM of each sample was weighed into a polyester bag (catalog no. 07-51/33, $85 \times 160 \mathrm{~mm}$, mean pore size $51 \mu \mathrm{m}$; Sefar Filtration, Inc., Depew, NY). Sample and polyester bag preparation were done on the day before incubation, which allowed an enzyme-substrate interaction time at room temperature of approximately $16 \mathrm{~h}$. Sixteen polyester bags were incubated in each animal: 4 each of alfalfa silage, alfalfa silage treated with enzyme, barley silage, and barley silage treated with enzyme.

Following $24 \mathrm{~h}$ of ruminal incubation, all bags were retrieved and placed in ice water to stop the fermentation. The bags were subsequently rinsed under a gentle stream of cold water until the water ran clear. Excess fluid was carefully squeezed from the bags and the bags were oven-dried at $60^{\circ} \mathrm{C}$ for $48 \mathrm{~h}$. Residues were analyzed for DM, NDF, and ADF content, and disappearance values were determined and expressed as a proportion of DM, NDF, and ADF incubated, respectively.

\section{Lactation Study}

The lactation study was conducted at the University of Alberta DRTC, Edmonton, Alberta, Canada. The experimental protocol was approved by the Faculty Animal Policy and Welfare Committee at the University of Alberta. Cows were housed in a ventilated, individual tie-stall barn, had free access to water, and were exercised daily $(2 \mathrm{~h})$ in an open dry lot.

Animals and Diets. Sixty lactating Holstein dairy cows (30 primiparous and 30 multiparous; $46 \pm 10$ DIM at the start of the experimental period) were blocked by parity and then randomly assigned to 1 of 3 treatments: (1) CTL diet (no enzyme), (2) low enzyme (LE; CTL treated with $0.5 \mathrm{~mL}$ of Econase RDE $/ \mathrm{kg}$ of TMR DM), and (3) high enzyme (HE; CTL treated with $1.0 \mathrm{~mL}$ of Econase RDE/kg of TMR DM). All cows were fed the DRTC standard early-lactation diet for 2 wk (covariate period) followed by a 10 -wk period (experimental period) on their assigned diet. The cows were fed for ad libitum intake once daily at $0800 \mathrm{~h}$. The CTL diet (Table 1) was formulated using the Cornell-Penn-Miner System (CPMDairy, Version 3.0.4a; Cornell University, Ithaca, NY; University of Pennsylvania, Kennett Square, PA; and William H. Miner Agricultural Research Institute, Chazy, NY) to provide adequate ME and MP for a $605-\mathrm{kg}$ cow producing $39 \mathrm{~kg} / \mathrm{d}$ of milk containing $3.5 \%$ fat and $3.3 \%$ protein, and assuming a DMI of $23 \mathrm{~kg} / \mathrm{d}$. Preparation of the diets and addition of the enzyme, and water in the case of the CTL diet, were similar to the procedures described for the in situ study. The forages and concentrate were sampled weekly to determine $\mathrm{DM}$ contents $\left(48 \mathrm{~h}\right.$ at $\left.60^{\circ} \mathrm{C}\right)$, and 
the diets and amount of enzyme added were adjusted to account for changes in the DM contents.

Samples and Measurements. Body weight was recorded at the beginning and the end of the experimental period to determine gain or loss of BW. Feed offered and feed refused were measured and recorded daily during the covariate and experimental periods. Dry matter content $\left(48 \mathrm{~h}\right.$ at $\left.60^{\circ} \mathrm{C}\right)$ of the TMR and the orts for individual cows was determined weekly to calculate DMI. Samples of the CTL TMR, diet ingredients (forages and concentrate), and orts for individual cows were collected every $2 \mathrm{wk}$; orts samples were collected for 3 consecutive days and TMR and diet ingredients on $1 \mathrm{~d}$ during sampling weeks. These samples were dried for $48 \mathrm{~h}$ at $60^{\circ} \mathrm{C}$, ground through a 1-mm-screen Wiley mill (standard model 4; Arthur H. Thomas Co.), and stored for subsequent nutrient content analyses.

Cows were milked in their stalls twice daily at 0400 and $1400 \mathrm{~h}$. Milk weight was recorded daily (a.m. and p.m.) during the covariate and experimental periods from each cow to determine milk production. Milk samples were taken on 3 consecutive days, once during the covariate period and every 2 wk during the experimental period. Samples were preserved with potassium dichromate, stored at $4^{\circ} \mathrm{C}$, and sent to the Central Alberta Milk Testing Laboratory (Edmonton, $\mathrm{AB}$, Canada) for milk fat, $\mathrm{CP}$, and lactose analyses using an infrared analyzer (Milk-O-Scan 605, Foss Electric, Hillerød, Denmark; AOAC, 2002; method 972.16). Milk component percentage and weight were adjusted for a.m. and p.m. milk weights.

Blood samples were taken from the coccygeal vessel every $18 \mathrm{~h}$ over a 3 -d period $(1300,0700,0100$, and 1900 $\mathrm{h}$, representing every 6 -h of a 24 -h period accounting for diurnal variation) in the last week of the covariate period and during wk 2, 6, and 10 of the experimental period. Blood was sampled into Vacutainer tubes containing sodium heparin (Becton Dickinson, Franklin Lakes, NJ), immediately placed on ice and centrifuged at $3,000 \times g$ for 30 min at $4^{\circ} \mathrm{C}$ within $1 \mathrm{~h}$ after collection. Plasma was harvested and stored at $-20^{\circ} \mathrm{C}$ until the end of the sampling week, at which point plasma samples were pooled by cow and again stored at $-20^{\circ} \mathrm{C}$ until further analysis.

\section{Chemical Analysis}

Chemical analyses were performed on each sample in duplicate, and analysis was repeated when the coefficient of variation was $>5 \%$. Analytical DM was determined by drying samples at $135^{\circ} \mathrm{C}$ for $2 \mathrm{~h}$, followed by hot weighing (AOAC, 1995; method 930.05). The OM content was calculated as the difference between 100 and the percentage ash (AOAC, 1995; method 942). The NDF was determined as described by Van Soest et al. (1991) using heat-stable $\alpha$-amylase (Termamyl 120L, Novo Nordisk Biochem, Franklinton, NC) and sodium sulfite, and ADF was determined according to AOAC (1995; method 973.18). For the measurement of $\mathrm{CP}(\mathrm{N} \times 6.25)$, samples were ground using a ball mill (Mixer Mill MM2000, Retsch, Haan, Germany) to a fine powder, and total $\mathrm{N}$ was quantified by flash combustion and thermal conductivity detection (Carlo Erba Instruments, Milan, Italy).

Commercial kits were used to determine plasma concentrations of insulin (Coat-A-Count Insulin, 2006) and NEFA (NEFA C-kit, Wako Chemicals USA, Richmond, VA) using a described previously protocol modification (Johnson and Peters, 1993). Plasma glucose concentration was measured using a glucose oxidase-peroxidase enzyme (Sigma Chemical Co., catalog no. P-7119) and dianisidine dihydrochloride (Sigma Chemical Co., catalog no. D-3252; Sigma Technical Bulletin, 2003). Absorbance was determined at the wavelength of 450 nm with a plate reader (SpectraMax 190, Molecular Devices Corp., Sunnyvale, CA). Plasma BHBA concentration was determined using the enzymatic oxidation of BHBA to acetoacetate with 3-hydroxybutrate dehydrogenase (Roche, Mississauga, Ontario, Canada; catalog no. H6501), and the concomitant reduction of NAD to NADH was determined using a plate reader at the wavelength of $340 \mathrm{~nm}$ (Williamson et al., 1962).

\section{Statistical Analysis}

Data were analyzed with the mixed model procedure (SAS Institute, 2001). For the in vitro study, data for alfalfa hay, alfalfa silage, and barley silage were analyzed separately as completely randomized designs. The model was as follows:

$$
y_{i j k}=L_{i}+R_{j}+L R_{i j}+\varepsilon_{i j k},
$$

where $y_{i j k}$ was the dependent variable; dose level $\left(L_{i}\right)$ was considered the treatment effect and analyzed as a fixed variable; incubation run $\left(R_{j} ; \mathrm{n}=4\right)$ was considered a random variable; the interaction between dose level and incubation run $\left(L R_{i j}\right)$ was also a random variable; and $\varepsilon_{i j k}$ was the random error. The LSM for each dose level was compared against the CTL with the PDIFF command invoked and using the Dunnett adjustment only when the treatment effect for a response variable was significant $(P<0.05)$.

Data for alfalfa silage and barley silage from the in situ incubation were analyzed separately using a completely randomized design. The model was as follows: 
Table 2. In vitro DM, NDF, and ADF disappearance after a 24-h batch culture fermentation of alfalfa hay, alfalfa silage, and barley silage with addition of a developmental fibrolytic enzyme at 4 doses

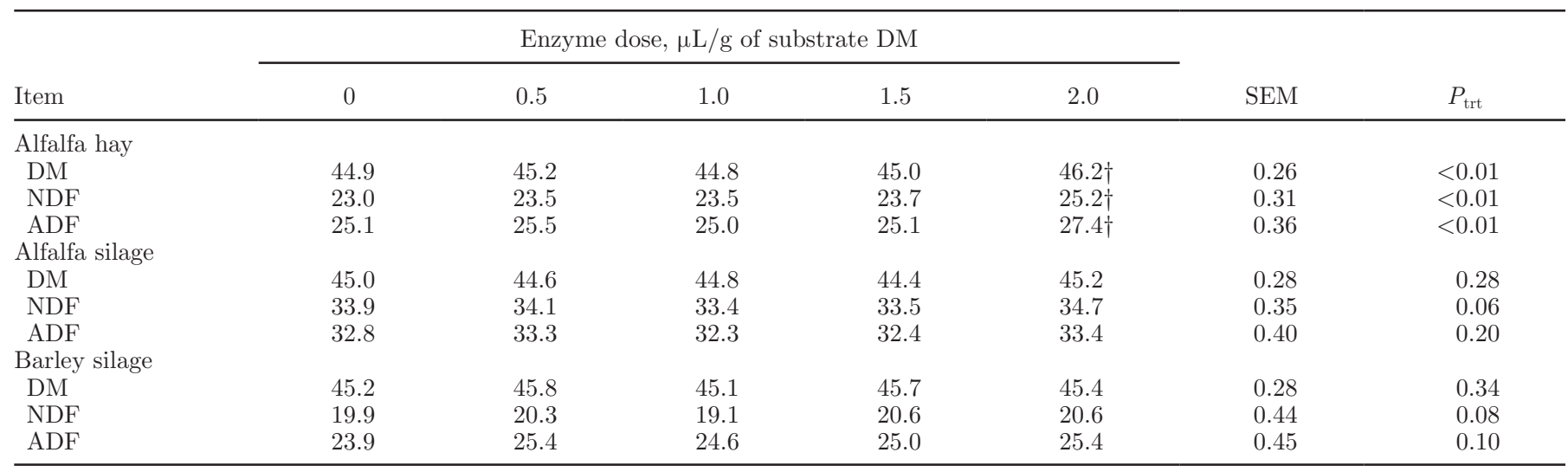

$\dagger$ LSM differed from control $($ dose $=0), P<0.05$. Treatment LSM was compared against the control with the PDIFF command invoked and using the Dunnett adjustment.

$$
\begin{gathered}
y_{i j k l}=D_{i}+T_{j}+D T_{i j}+C_{k}+D C_{i k}+T C_{j k} \\
+D T C_{i j k}+\varepsilon_{i j k l} .
\end{gathered}
$$

The diet $\left(D_{i}\right.$; CTL or enzyme-treated) the cannulated cows received and the treatment of the silage substrates ( $T_{j}$; with or without enzyme) were considered fixed variables, whereas cow $\left(C_{k}\right)$ and all interactions with cow $\left(D C_{i k}, T C_{j k}, D T C_{i j k}\right)$ were considered random variables.

The lactation study data were analyzed as a completely randomized block (parity) design. In the model parity $\left(P_{i}\right)$, enzyme treatment $\left(T_{j}\right)$, week $\left(W_{k}\right)$, and their interaction terms were considered fixed variables, and cow $\left(C_{l}\right)$ and its interaction terms were considered random variables. Body weight, feed intake, milk production, and blood measurement data were weighted in the analyses using the value of the respective measurements recorded during the covariate period $\left(C O V_{x}\right.$; where $x=$ measurement, e.g., BW). Milk production and DMI data were analyzed as repeated measurements using the weekly means. Blood measurement data were also analyzed as repeated measurements. There was no week by treatment interaction and no interaction of parity with any other parameter. These terms were therefore removed from the final statistical model. The final model was as follows:

$$
y_{i j k l m}=C O V_{x}+P_{i}+T_{j}+W_{k}+C_{l}+T C_{j l}+\varepsilon_{i j k l m} .
$$

A linear regression analysis for the effect of increasing amount of enzyme added was performed for measurements with a significant treatment effect by using a contrast statement. Also, the LSM for each treatment level was compared against the CTL with the PDIFF command invoked and using the Dunnett adjustment only when the treatment effect for a response variable was significant. Significance was declared at $P \leq 0.05$ and a tendency to significance at $0.05 \leq P<0.10$.

\section{RESULTS}

\section{In Vitro Fermentation}

The DM, NDF, and ADF disappearance of alfalfa hay was increased with the addition of $2 \mu \mathrm{L}$ of enzyme/g of substrate DM compared with the CTL (Table 2). Lower levels of enzyme addition ( 0.5 to $1.5 \mu \mathrm{L} / \mathrm{g}$ of substrate DM) had no effect on DM and fiber disappearance from alfalfa hay. Barley silage DM and alfalfa silage DM and ADF disappearance were not affected by enzyme addition. Barley silage NDF $(P=0.08)$ and $\operatorname{ADF}(P=$ $0.10)$ and alfalfa silage $\operatorname{NDF}(P=0.06)$ disappearance tended to increase with enzyme addition.

\section{In Situ Incubation}

No effect of the host animal's diet and no interaction between enzyme addition to the substrates and the host animal's diet were observed on in situ DM, NDF, and ADF degradability of alfalfa and barley silage (Table $3)$. There was also no effect of enzyme addition on in situ DM and NDF degradability of alfalfa and barley silage, and ADF degradability of barley silage. In situ ADF degradability of alfalfa silage was numerically greater with enzyme addition, but this difference was not statistically significant $(P=0.19)$.

\section{Lactation Study}

Performance and Production. No parity effect or treatment by parity interaction was observed for any of 
Table 3. In situ DM, NDF, and ADF disappearance of alfalfa and barley silage with $(+\mathrm{E})$ or without enzyme $(-\mathrm{E})$ addition incubated for 24 $\mathrm{h}$ in lactating dairy cows fed a control or enzyme-supplemented $(1.0 \mathrm{~mL} / \mathrm{kg}$ of TMR DM) diet

\begin{tabular}{|c|c|c|c|c|c|c|c|}
\hline \multirow[b]{2}{*}{ Item } & \multicolumn{2}{|c|}{ Control diet } & \multicolumn{2}{|c|}{ Enzyme (E) diet } & \multirow[b]{2}{*}{ SEM } & \multicolumn{2}{|c|}{$P$-value ${ }^{1}$} \\
\hline & $-\mathrm{E}$ & $+\mathrm{E}$ & $-\mathrm{E}$ & $+\mathrm{E}$ & & Enzyme & Diet \\
\hline NDF, $\%$ & 24.8 & 28.8 & 26.4 & 28.2 & 3.47 & 0.43 & 0.88 \\
\hline ADF, $\%$ & 35.6 & 40.7 & 37.1 & 40.6 & 2.99 & 0.19 & 0.82 \\
\hline \multicolumn{8}{|c|}{ Barley silage } \\
\hline $\mathrm{ADF}, \%$ & 30.3 & 32.6 & 32.4 & 31.7 & 1.38 & 0.56 & 0.70 \\
\hline
\end{tabular}

${ }^{1}$ No interaction between enzyme and diet; $P>0.05$.

the performance and production measurements. Initial and final BW and ADG did not differ among treatments (Table 4). Adding enzyme to the diet decreased DMI, with the decline in intake proportional to the dose of the enzyme (linear regression, $P<0.05$ ). Dry matter intake of cows on the HE diet was lower $(P=0.01)$ than for cows on the CTL diet, whereas DMI tended $(P=0.08)$ to be lower for cows on the LE diet than for CTL cows. Milk yield, 3.5\% FCM, and milk composition did not differ among dietary treatments. Milk component yields also did not differ among treatments. Milk production efficiency ( $\mathrm{kg}$ of milk $/ \mathrm{kg}$ of DMI) and FCM production efficiency ( $\mathrm{kg}$ of $\mathrm{FCM} / \mathrm{kg}$ of DMI) increased linearly with increasing enzyme addition $(P$ $=0.01$ and $P<0.01$, respectively). At the lower dose of the enzyme, production efficiency was intermediate and did not differ from that in the CTL treatment $(P=$ 0.34 and $P=0.33$, milk production and FCM produc- tion efficiency, respectively), whereas it was increased for cows receiving the $\mathrm{HE}$ diet compared with cows on the CTL diet $(P=0.03$ and $P=0.01$, milk production and FCM production efficiency, respectively).

Blood Measurements. Compared with that in CTL cows, plasma BHBA concentration for cows receiving the LE diet was similar $(P=0.71)$, whereas that of cows receiving the HE diet was lower $(P=0.02)$ (Table 5). Plasma NEFA concentration was similar among treatments. Plasma insulin concentration was higher for the HE $(P<0.01)$ cows compared with cows receiving the CTL diet, whereas LE cows had similar $(P=$ 0.24) insulin concentrations to the CTL cows.

\section{DISCUSSION}

Adding a high level $(1.0 \mathrm{~mL} / \mathrm{kg}$ of TMR DM $)$ of enzyme to the diet of cows in early lactation increased

Table 4. Production results for cows receiving a control diet or enzyme-treated diet at a low $(0.5 \mathrm{~mL} / \mathrm{kg}$ of TMR DM) or high $(1.0 \mathrm{~mL} / \mathrm{kg}$ of TMR DM) dose

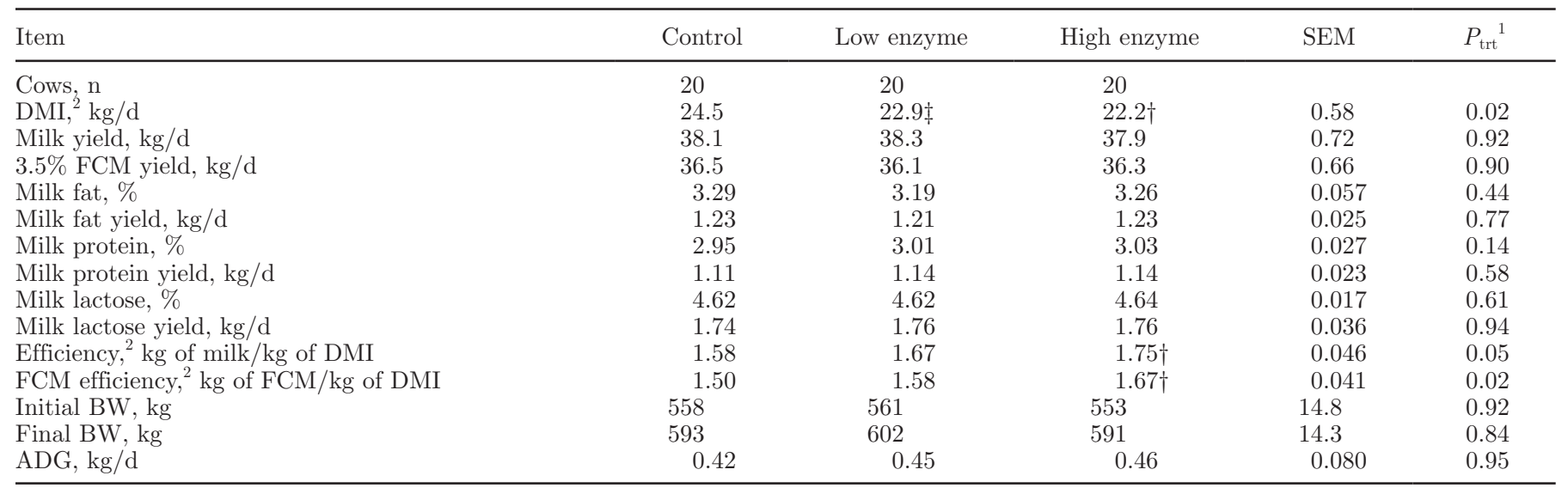

${ }^{1}$ No effect of parity or interactions between treatment and parity; $P>0.05$.

${ }^{2}$ Linear effect with increasing enzyme level; $P<0.05$.

$\dagger$ Treatment LSM differ from control LSM; $P<0.05$. Treatment LSM was compared against the control with the PDIFF command invoked and using the Dunnett adjustment.

$\ddagger$ Treatment LSM tend to differ from control LSM; $0.05 \leq P<0.10$. 
Table 5. Blood variables for cows receiving a control diet or enzyme-treated diet at a low $(0.5 \mathrm{~mL} / \mathrm{kg}$ of TMR $\mathrm{DM})$ or high $(1.0 \mathrm{~mL} / \mathrm{kg}$ of TMR DM) dose

\begin{tabular}{lccccc}
\hline Item & Control & Low enzyme & High enzyme & SEM & $P_{\text {trt }}{ }^{1}$ \\
\hline Number of cows & 20 & 20 & 20 & & \\
BHBA, mg/dL & 14.8 & 14.5 & $13.7 \dagger$ & 0.30 & 0.03 \\
NEFA, $\mu \mathrm{Eq} / \mathrm{L}$ & 94.7 & $82.6 \ddagger$ & 85.2 & 4.56 & 0.16 \\
Insulin, IU/mL & 6.44 & 7.41 & $8.45 \dagger$ & 0.462 & 0.01 \\
Glucose, $\mathrm{mg} / \mathrm{dL}$ & 56.8 & 58.0 & 58.2 & 0.88 & 0.48 \\
\hline
\end{tabular}

${ }^{1}$ No effect of parity or interactions between treatment and parity; $P>0.05$.

$\dagger$ Treatment LSM differ from control LSM; $P<0.05$. Treatment LSM was compared against the control with the PDIFF command invoked and using the Dunnett adjustment.

$\ddagger$ Treatment LSM tend to differ from control LSM; $0.05 \leq P<0.10$.

milk production efficiency ( $\mathrm{kg}$ of milk/kg of DMI) by $10.7 \%$ and FCM production efficiency $(\mathrm{kg}$ of $\mathrm{FCM} / \mathrm{kg}$ of DMI) by $11.3 \%$. Improvements in feed conversion efficiency were due to lower DMI rather than a change in milk yield. A low level $(0.5 \mathrm{~mL} / \mathrm{kg}$ of TMR DM) of enzyme did not improve milk production efficiency or FCM production efficiency, but the responses were numerically intermediate (5.7 and $5.3 \%$, respectively) compared with that in CTL and HE cows. Improved feed efficiency indicates better utilization of nutrients when TMR was treated with enzymes, with the magnitude of improvement being a linear function of enzyme dosage.

The improvement in feed conversion efficiency observed in the lactation study might be attributable to greater NDF digestibility in the rumen. In the in vitro study, addition of the developmental enzyme additive resulted in an increase or tendency for an increase in NDF digestibility of the 3 forages, with the most consistent effects seen for alfalfa hay. A high degree of variability in the in situ study, indicated by the greater SE compared with those in the in vitro study, may have prevented us from detecting significant treatment effects. It appears that in vitro evaluation is the preferred method of evaluating the effects of enzyme on NDF degradation, due to the ability to minimize variability associated with differences among cows (i.e., rumen $\mathrm{pH}$, rumen microbial populations). In our in vitro study, effects on forage NDF degradation were observed at the highest dose $(2 \mu \mathrm{L} / \mathrm{g}$ of forage DM; $1,444 \mathrm{nmol}$ of endoglucanase and 5,208 nmol of xylanase, at $39^{\circ} \mathrm{C}$ and $\mathrm{pH}$ 6), which in the case of alfalfa hay increased in vitro digestibility of NDF and ADF by 9.6 and $9.2 \%$, respectively.

It is difficult to compare the dosages used in vitro to those used in vivo. In the in vitro study, the enzyme was applied to the individual forages, whereas in the lactation study, the enzyme was applied to the TMR. If one assumes that the enzyme acts only on the forage NDF in the diet, the high dosage rate in vivo $[1 \mathrm{~mL} / \mathrm{kg}$ of TMR DM, or $1.9 \mu \mathrm{L} / \mathrm{g}$ of forage DM ( $52 \%$ forage in the diet on a DM basis)] is equivalent to the highest dosage rate in vitro $(2 \mu \mathrm{L} / \mathrm{g}$ of forage $\mathrm{DM})$. Adding the enzyme to the TMR is a convenient method of application onfarm, but it dilutes the enzyme-to-forage-NDF ratio because of the presence of concentrates in the TMR. In the in vivo study, $70 \%$ of the diet NDF was forage NDF. Assuming that the added enzyme was equally distributed between forage and concentrate NDF, the high dosage rate had an enzyme-to-forage-NDF ratio of only $2 \mu \mathrm{L} / \mathrm{g}$ of forage NDF $[1 \mathrm{~mL} / \mathrm{kg}$ of TMR DM $\div$ $0.339(\% \mathrm{NDF}$ in diet $) \times 70 \%$ (NDF supplied by forage $)=2.06 \mathrm{~mL} / \mathrm{kg}$ forage NDF or $2 \mu \mathrm{L} / \mathrm{g}$ forage NDF] In the in vitro study, the enzyme-to-forage-NDF ratio at the highest dosage rate was $4.2,5.4$, and $3.8 \mu \mathrm{L} / \mathrm{g}$ of NDF for alfalfa hay, alfalfa silage, and barley silage, respectively. Despite the lower dosages used in vivo, feed efficiency increased. These calculations illustrate the difficulties of establishing the effective in vivo dose range for enzymes based on in vitro screening.

It is clear from our study that enzyme dosage can influence the effectiveness of enzyme products in vivo, as observed previously (Beauchemin et al., 1995; Lewis et al., 1999). Lewis et al. (1999) added a xylanase-cellulase enzyme solution to a dairy cow TMR based on alfalfa hay and silage, and reported an increase in milk production for the intermediate enzyme dosage compared with the low or high levels of enzyme addition. It is difficult to compare the dosages in our study with those used by Lewis et al. (1999) because a different enzyme product was used and the conditions under which the enzymatic activities were determined were not given. The optimal dose for the developmental enzyme product was not determined in the current study.

The effects of enzyme additives in in vivo studies have been quite variable. The review by Beauchemin et al. (2003b) reported an increase in milk yield of 1.1 $\pm 1.5 \mathrm{~kg} / \mathrm{d}$ with exogenous fibrolytic enzyme addition when combining data from 20 studies and 41 treatments. The high standard deviation indicates the variability in response among studies for a variety of enzyme products and experimental conditions. Although 
some authors reported an increase in milk production (Lewis et al., 1999; Kung et al., 2000), others reported no response (Higginbotham et al., 1996; Schingoethe et al., 1999). Beauchemin et al. (2003b) also found an overall increase of $1.0 \pm 1.3 \mathrm{~kg} / \mathrm{d}$ in DMI with the addition of fibrolytic exogenous enzymes to dairy cattle diets. Some studies have reported no effects on DMI of lactating dairy cows (Rode et al., 1999; Yang et al., 2000; Adesogan et al., 2007), but no other report of decreased DMI, as observed in the current study, was found in the literature.

Cows on the HE diet decreased their DMI without changing milk production. One could speculate that the response might have been different had the diet been energy limiting. The ME intake of the CTL cows exceeded their requirements for milk production as estimated using the CPM dairy model (i.e., the diet was formulated for $39 \mathrm{~kg} / \mathrm{d}$ of FCM). To this end, lower plasma BHBA concentration and greater plasma insulin concentration for HE compared with CTL treatment indicated improved energy status of cows receiving the HE diet. The lower BHBA concentration of cows receiving the $\mathrm{HE}$ diet indicates decreased fat mobilization, although this effect was not reflected in the plasma NEFA concentration (another indicator of fat mobilization). However, the lack of treatment effects for plasma concentration of glucose as well as NEFA, despite the lower feed intake of cows fed enzyme diets, supports the speculation that the enzymes improved the energy availability of the diet.

\section{CONCLUSIONS}

The developmental enzyme product improved FCM production efficiency for early-lactation dairy cows by $11.3 \%$, but its effect depended upon the dosage. This improvement in production efficiency might be due in part to the increase in NDF digestibility of forage with addition of the enzyme. The stepwise approach taken in this study provided an appropriate characterization of enzymic activity of the developmental enzyme product for use in ruminant diets. Further work is necessary to determine if the enzyme additive would be effective for other types of feedstuffs and what the optimal dosage for different enzyme-substrate combinations would be.

\section{ACKNOWLEDGMENTS}

We thank the personnel at the University of Alberta Dairy Research and Technology Center (Edmonton, Alberta, Canada) for caring for the cows used in these studies.

\section{REFERENCES}

Adesogan, T. A., S.-C. Kim, K. G. Arriola, D. B. Dean, and C. R. Staples. 2007. Strategic addition of dietary fibrolytic enzymes for improved performance of lactating dairy cows. Pages 92-110 in Proc. 18th Annu. Florida Rum. Nutr. Symp., Univ. Florida, Gainesville, FL. University of Florida, Gainesville.

AOAC. 1995. Official Methods of Analysis. 16th ed. Association of Official Analytical Chemists, Arlington, VA.

AOAC. 2002. Official Methods of Analysis. 17th ed. Association of Official Analytical Chemists, Gaithersburg, MD.

Bailey, M. J., P. Biely, and K. Poutanen. 1992. Interlaboratory testing of methods for assay of xylanase activity. J. Biotechnol. 23:257270 .

Beauchemin, K. A., D. Colombatto, and D. P. Morgavi. 2003a. A rationale for the development of feed enzyme products for ruminants. Can. J. Anim. Sci. 84:23-36.

Beauchemin, K. A., D. Colombatto, D. P. Morgavi, and W. Z. Yang. 2003b. Use of exogenous fibrolytic enzymes to improve feed utilization by ruminants. J. Anim. Sci. 81(E. Suppl. 2):E37-E47.

Beauchemin, K. A., L. M. Rode, and V. J. H. Sewalt. 1995. Fibrolytic enzymes increase fiber digestibility and growth rate of steers fed dry forages. Can. J. Anim. Sci. 75:641-644.

Bhat, M. K., and G. P. Hazlewood. 2001. Enzymology and other characteristics of cellulases and xylanases. Pages 11-60 in Enzymes in Farm Animal Nutrition. M. Bedford and G. Partridge, ed. CABI Publishing, Wallingford, UK.

Canadian Council on Animal Care. 1993. Guide to the Care and Use of Experimental Animals. Vol. 1. 2nd ed. E. D. Olfert, B. M. Cross, and A. A. McWilliam, ed. CCAC, Ottawa, ON, Canada.

Coat-A-Count Insulin. 2006. PITKIN-5: Coat-a-count insulin package insert. Siemens Medical Solutions Diagnostics, Los Angeles, CA. Accessed August 11, 2010. http://www.medicalsystems.it/MetodicheSiemens/RIA/pitkin-5_siemens.pdf.

Colombatto, D., and K. A. Beauchemin. 2003. A proposed methodology to standardize the determination of enzymic activities present in enzyme additives used in ruminant diets. Can. J. Anim. Sci. 83:559-568.

Feng, P., C. W. Hunt, G. T. Pritchard, and W. E. Julien. 1996. Effect of enzyme preparations on in situ and in vitro degradation and in vivo digestive characteristics of mature cool-season grass forage in beef steers. J. Anim. Sci. 74:1349-1357.

Goering, H. K., and P. J. Van Soest. 1970. Forage Fiber Analyses (Apparatus, Reagents, Procedures, and Some Applications). Agric. Handbook No. 379. ARS-USDA, Washington, DC.

Higginbotham, G. E., E. J. dePeters, S. L. Berry, and A. Ahmadi. 1996. Effect of adding a cell wall degrading enzyme to a total mixed ration for lactating dairy cows. Prof. Anim. Sci. 12:81-85.

Huntington, J. A., and D. I. Givens. 1995. The in situ technique for studying the rumen degradation of feeds: A review of the procedure. Nutr. Abs. Rev. Ser. B 65:64-93.

Johnson, M. M., and J. P. Peters. 1993. Technical note: An improved method to quantify nonesterified fatty acids in bovine plasma. J. Anim. Sci. 71:753-756.

Kung, L. Jr., M. A. Cohen, L. M. Rode, and R. J. Treacher. 2002. The effect of fibrolytic enzymes sprayed onto forages and fed in a total mixed ratio to lactation dairy cows. J. Dairy Sci. 85:2396-2402.

Kung, L. Jr., R. J. Treacher, G. A. Nauman, A. M. Smagala, K. M. Endres, and M. A. Cohen. 2000. The effect of treating forages with fibrolytic enzymes on nutritive value and lactation performance of dairy cows. J. Dairy Sci. 83:115-122.

Lewis, G. E., W. K. Sanchez, C. W. Hunt, M. A. Guy, G. T. Pritchard, B. I. Swanson, and R. J. Treacher. 1999. Effect of direct-fed fibrolytic enzymes on the lactational performance of dairy cows. J. Dairy Sci. 82:611-617.

Rode, L. M., W. Z. Yang, and K. A. Beauchemin. 1999. Fibrolytic enzyme supplements for dairy cows in early lactation. J. Dairy Sci. $82: 2121-2126$.

SAS Institute. 2001. SAS System for Windows. Release 9.1. SAS Inst. Inc., Cary, NC. 
Schingoethe, D. J., G. A. Stegeman, and R. J. Treacher. 1999. Response of lactating dairy cows to a cellulose and xylanase enzyme mixture applied to forages at the time of feeding. J. Dairy Sci. 82:996-1003.

Sigma Technical Bulletin. 2003. PGO Enzymes Technical Bulletin. Sigma-Aldrich Corporation, St. Louis, MO. Accessed August 11, 2010. http://www.sigmaaldrich.com/etc/medialib/docs/Sigma/ Bulletin/p7119bul.Par.0001.File.tmp/p7119bul.pdf.

Van Soest, P. J., J. B. Robertson, and B. A. Lewis. 1991. Methods for dietary fiber, neutral detergent fiber and nonstarch polysaccharides in relation to animal nutrition. J. Dairy Sci. 74:3583-3597.

Williamson, D. H., J. Mellanby, and H. A. Krebs. 1962. Enzymic determination of $\mathrm{D}(-)$-b-hydroxybutyric acid and acetoacetic acid in blood. Biochem. J. 82:90-96.
Wood, T. M., and M. K. Bhat. 1998. Methods for measuring cellulose activities. Pages 87-112 in Methods in Enzymology. Vol. 160. W. A. Wood and S. T. Kellogg, ed. Academic Press Inc., London, UK.

Yang, W. Z., K. A. Beauchemin, and L. M. Rode. 1999. Effects of an enzyme feed additive on extent of digestion and milk production of lactating dairy cows. J. Dairy Sci. 82:391-403.

Yang, W. Z., K. A. Beauchemin, and L. M. Rode. 2000. A comparison of methods of adding fibrolytic enzymes to lactating cow diets. J. Dairy Sci. 83:2512-2520. 